\title{
Review \\ Therapeutic angiogenesis for cardiovascular disease
}

Yin-Shan $\mathrm{Ng}$ and Patricia A D'Amore

Schepens Eye Research Institute, Departments of Ophthalmology and Pathology, Harvard Medical School, Boston, Massachusetts, USA

Correspondence: Patricia A D’Amore, pdamore@vision.eri.harvard.edu

Published online: 24 October 2001

Curr Control Trials Cardiovasc Med 2001, 2:278-285

(C) 2001 BioMed Central Ltd (Print ISSN 1468-6708; Online 1468-6694)

\begin{abstract}
The identification of angiogenic growth factors, such as vascular endothelial growth factor and fibroblast growth factor, has fueled interest in using such factors to induce therapeutic angiogenesis. The results of numerous animal studies and clinical trials have offered promise for new treatment strategies for various ischemic diseases. Increased understanding of the cellular and molecular biology of vessel growth has, however, prompted investigators and clinicians alike to reconsider the complexity of therapeutic angiogenesis. The realization that formation of a stable vessel is a complex, multistep process may provide useful insights into the design of the next generation of angiogenesis therapy.
\end{abstract}

Keywords collateral, endothelial cells, ischemia, neovascularization, vascular endothelial growth factor

Angiogenesis is the growth of blood vessels from a pre-existing vessel bed. Clinical interest in the control of angiogenesis arises from two distinct quarters. In one case, the goal is to block the growth of new vessels as a means to suppress and/or regress tumor growth, or to suppress vessel proliferation in pathologies such as diabetes. In the second case, the objective is to induce or stimulate vessel growth in patients with conditions characterized by insufficient blood flow, such as ischemic heart disease and peripheral vascular diseases. The latter applications are the focus of this review. We discuss some of the recent efforts to induce new vessel growth and we highlight challenges that have arisen regarding the means of delivery and efficacy of angiogenesis induction.

\section{Angiogenic stimuli}

Both basic fibroblast growth factor (FGF-2) and vascular endothelial growth factor (VEGF)-A have been used in attempts to stimulate angiogenesis.

\section{Fibroblast growth factor}

The fibroblast growth factor (FGF) family consists of an everincreasing number of peptide growth factors with diverse cellular targets and biological effects [1]. Two family members, acidic fibroblast growth factor (FGF-1) and FGF-2, have a strong affinity for heparin and have been studied for their effects on vascular cells, including endothelial cells and smooth muscle cells. Extensive evidence indicates that both FGF-1 and FGF-2 are potent angiogenic factors, providing support for their use as stimuli for therapeutic angiogenesis in vivo. It is also important to note that many cell types express one of the four FGF receptors, and that FGF has been shown to have biological effects in a number of cell systems including induction of neurite outgrowth, suppression of skeletal muscle differentiation, induction of bone formation and neuroprotection, to name just a few.

\section{Vascular endothelial growth factor-A}

VEGF-A is the prototypic member of a family of secreted, homodimeric glycoproteins with endothelial cell-specific mitogenic activity and the ability to stimulate angiogenesis in vivo [2]. VEGF-A also increases vascular permeability, with an effect 10,000 times more potent than that of the vasoactive substance histamine; VEGF-A was originally purified based on this property, and was named vascular permeability factor [3]. The VEGF-A family of polypeptides consists of a number

ang $=$ angiopoietin; $\mathrm{CEP}=$ circulating endothelial precursor; FGF $=$ fibroblast growth factor; FGF-1 = acidic fibroblast growth factor; FGF-2 = basic fibroblast growth factor; HIF-1 $\alpha=$ hypoxia inducible factor-1 alpha; SPECT = single photon emission computed tomography; VEGF = vascular endothelial growth factor. 
of biochemically distinct isoforms (three isoforms in the mouse and up to five in humans) that are generated through alternative mRNA splicing of a single gene [4,5]. The isoforms are named by the number of amino acids that comprise the proteins; the human isoforms include VEGF121, VEGF145, VEGF165, VEGF189, and VEGF206.

\section{Preclinical studies}

Current clinical trials of angiogenesis factors were preceded by a large number of studies using animal models of cardiac or peripheral ischemia. Early studies involved protein administration, whereas later efforts began to employ gene therapy. In one early study using recombinant protein, a single intraarterial injection of 500-1000 $\mu \mathrm{g}$ VEGF165 into rabbits with severe experimental hind limb ischemia increased collateral vessels, as detected by angiography and histological analysis [6]. Naked plasmid DNA injected directly into the skeletal muscle in a later study, using the same hind limb ischemia model, also yielded increased collateral vessels, as determined by angiography and improved perfusion [7].

Although such reports of increased vessel growth and functional improvement in response to exogenously administered angiogenic factors are encouraging, it is essential to note that animal models such as the ischemic hind limb model have definite limitations. Whereas the ischemia in the animal models is acute (produced by surgical procedure), the ischemia that characterizes the human disease often arises over an extended time and occurs in the context of complex atherosclerotic processes. The responses seen in the experimental models may thus be quite different in terms of the kinetics of vessel growth as well as the nature of the resultant vessels.

In a study assessing the effects of VEGF-A on myocardial ischemia in a porcine model of progressive coronary artery occlusion, VEGF-A was delivered by osmotic pump and magnetic resonance mapping revealed a reduction in the size of the ischemic zone and improved cardiac function [8]. A single bolus injection was also found to produce significant improvements in myocardial blood flow and function [9]. Myocardial ischemia in animals has also been treated with FGF. Delivery of FGF-2 via implantation of heparin-alginate beads led to an $80 \%$ reduction in infarct size and improved cardiac function in pigs with experimentally induced coronary artery constrictions, as compared with untreated controls [10]. These studies were followed closely by the demonstration of gene therapy in a porcine model of stress-induced myocardial ischemia. Intracoronary injection of a recombinant adenovirus expressing another member of the FGF family, human FGF-5, led to improvements in stress-induced function and blood flow that were maintained for 12 weeks [11].

\section{Clinical trials}

Results from basic research have proven that both VEGF-A and FGF-2 are potent angiogenic factors, and the use of these factors in animal models has indicated that they have therapeutic potential. The two factors have therefore been entered into clinical trials, testing their ability to provide angiogenesis therapy for various diseases in which new vessel growth is desirable. Both VEGF-A and FGF-2 have been tested in phase I clinical trials, with mixed results $[12,13]$. Although phase I trials are not designed to test efficacy, many important insights regarding the potential obstacles to using angiogenic therapies have become evident.

\section{Fibroblast growth factor}

In one study, human recombinant FGF-2 was administered intraoperatively to areas of the coronary artery in 20 patients who were undergoing surgical revascularization [14]. Angiographic analysis revealed evidence of collateralization. Local sustained release of high dose (but not low dose) FGF-2 to ischemic areas, in 24 patients during bypass surgery, led to a reduction in stress defect size [15]. In a recent study involving 59 patients with coronary disease, the response to intravenous or intracoronary human recombinant FGF-2 was monitored by single photon emission computed tomography (SPECT) imaging [16]. Perfusion was monitored at approximately 1, 2, and 3 months after growth factor administration. Analysis of global stress perfusion or inducible ischemia revealed a consistent and sustained reduction in the extent and severity of stress-inducible ischemia, as well as an improvement in resting perfusion in areas where there was a risk of ischemia.

\section{Vascular endothelial growth factor}

In an early phase I trial to test the safety and bioactivity of VEGF-A, naked VEGF165 DNA was injected into the myocardium of five patients who had failed standard therapy. SPECT imaging demonstrated reduced ischemia [17]. Adenoviral delivery of VEGF121 to the myocardium of 21 patients by direct injection, either as an adjunct to coronary bypass grafting or as the sole therapy, led to improvement in the area injected, as measured by angiography; angina was also reduced [18]. Administration of recombinant VEGF121 improved function, as detected by SPECT [19]. Furthermore, this study revealed a dose-dependent improvement in both stress perfusion and rest perfusion; there was an infrequent response in patients who received low dose VEGF and an improvement in five out of six patients who received high dose VEGF. In a different approach, VEGF cDNA was delivered via liposomes by catheter to coronary arteries following angioplasty [20]. While this phase I safety trial did not show an effect of VEGF-A on the degree of coronary ischemia, it did prove that the treatment was well tolerated.

It is important to note that no phase II controlled studies using defined and quantifiable endpoints have demonstrated efficacy of therapeutic angiogenesis. This highlights the main obstacles for assessing a therapeutic response to angiogenesis therapy, the reliability of the assessment methods and the possible complications of the placebo effect. There is thus a critical need for more controlled trials and for the development of better defined and more quantifiable endpoints. 


\section{Modes of delivery}

Delivery strategy is one of the most important variables when using angiogenic factors to treat pathological conditions. Expression of VEGF-A is tightly controlled during development, and slight changes in VEGF-A protein levels are associated with developmental abnormalities and embryonic lethality $\left[21,22^{*}\right]$. Additionally, the unregulated expression of VEGF-A in the myocardium has been reported to produce deleterious cardiac effects in an animal model, causing cardiac failure and death [23*0. Clearly, if VEGF-A is to be used for therapeutic angiogenesis, tight control of its levels must be achieved.

\section{Protein therapy}

At present, the administration of protein seems to be preferable to gene therapy [12]. This is mainly because dosage modulation in most clinical settings is far easier with purified protein than with gene therapy, which is hampered by the lack of a regulable expression vector. Although protein therapy has many advantages, there are nevertheless technical problems associated with protein administration, including optimization of purification and formulation of delivery for single and/or multiple angiogenic factors.

Recent advances in drug delivery methods using bioerodible polymer matrices will allow long-term sustained release of the growth factors [24]. This will resolve one of the major problems associated with protein administration; namely, the limited tissue half-life of the purified angiogenic factors in patients. An important consideration, however, is that protein therapy is limited to secreted factors. Delivery of intracellular modulators for therapeutic angiogenesis, including transcription factors that control angiogenesis such as hypoxia inducible factor- 1 alpha ( $\mathrm{HIF}-1 \alpha)$, is only possible through gene therapy.

\section{Gene therapy}

Viral vectors have been the most commonly used means of gene delivery for both VEGF-A and FGF-2. Gene therapy presents an attractive alternative to purified proteins because it offers the possibility of sustained production of one or more factors following a single administration. Furthermore, tissuespecific and highly localized production of the therapeutic factor is possible, through the use of tissue-specific promoters.

However, a variety of issues have implications for the use of viral vectors in gene therapy. Obvious potential concerns are the immune and inflammatory responses to viral vectors. Patients who received VEGF121 via an adenoviral vector had increased levels of serum anti-adenoviral neutralizing antibodies, but there was no report on an inflammatory response in these patients [19]. The use of adenovirus-mediated gene therapy in treating brain tumors has been reported to lead to active brain inflammation as well as persistent (up to 3 months after treatment) transgene expression [25].
The lack of regulable gene expression is another potential barrier. Some systems for inducible gene expressions have proved to be effective and safe in animal models [26], but have not yet been tested in humans. Recent advances in stem cell research provide the possibility of combining gene therapy with ex vivo gene transfer into stem cells for angiogenesis therapy, as will be discussed later. If successful, this approach may overcome most of the obstacles presented by gene therapy.

\section{Considerations for the future Interpatient variability}

It is not clear why some individuals develop a collateral circulation sufficient to compensate for their ischemic vascular disease whereas others do not. Certainly, features such as the extent of the disease and the time frame over which the ischemia develops are contributing factors. However, other previously unconsidered variables appear to play important roles.

Collateral vessel development, as measured by blood pressure, angiography, and vessel density, was significantly reduced in old (4-5 years old) versus young (6-8 months old) animals [27'], in a rabbit model of hind limb ischemia. Endothelial cell dysfunction and reduced VEGF-A levels were the reasons suggested for the reduced collateral response. $A$ subsequent study, demonstrating an age-dependent reduction in HIF- $1 \alpha$ activity, provides one explanation for the lower VEGF-A expression in response to hypoxia in aged animals [28]. A reduced response to hypoxia might translate into a weaker angiogenic response. This is supported by the fact that the extent of hypoxic induction of VEGF-A in monocytes correlates strongly with the presence of collateral vessels in patients [29].

It is possible that genetic variability may also play a significant role in an individual's ability to generate collateral vessels in response to ischemia, as well as their capacity to respond to an exogenous angiogenic agent. Not surprisingly, a recent report that assessed the angiogenic response in a murine corneal pocket model to a fixed dosage of FGF-2 in various strains of mice suggested that genetic backgrounds may influence angiogenic response [30*0. A nearly 10-fold range of response to the fixed dosage of FGF-2 was observed among different inbred strains of mice, suggesting that genetic variability may indeed play a significant role in determining the magnitude of angiogenic response to FGF-2.

\section{Systemic effects}

If VEGF-A delivery leads to significant circulating levels, as has been observed following myocardial transfection with VEGF-A cDNA [31], then it may possibly affect angiogenesis elsewhere [32]. As plaque progression might be dependent on angiogenesis [33], investigators were prompted to examine the effect of VEGF-A administration on this process. Mice that were double deficient in apolipoprotein $E$ and 
apolipoprotein $\beta 100$ were treated with a single intraperitoneal injection of VEGF165 recombinant human protein $(2 \mu \mathrm{g} / \mathrm{kg})$. This led to significant increases in plaque area compared with untreated controls [34*0. In contrast, there has been no evidence of disease progression, to date, in 42 patients treated with intra-arterial gene transfer of naked VEGF-A cDNA. This has been delivered either to promote therapeutic angiogenesis (12 patients) or to accelerate re-endothelization (30 patients) [35]. Although these observations suggest that human sensitivity to VEGF-A may be lower than in animal models, it will be necessary to study a larger cohort of patients, with appropriate controls, over a longer time period to confirm this [36].

VEGF has also been shown to mediate the vessel growth that characterizes tumor expansion as well as the neovascularization that is associated with diabetic retinopathy. Although VEGF is produced locally in both of these circumstances, it is not known whether systemic administration of the factor could exacerbate these conditions by further stimulating vessel growth. Selection of the patient population that may benefit from angiogenic therapy may thus have to involve screening for coexisting conditions that could be activated or worsened by exposure to proangiogenic agents.

VEGF-A, FGF-1, and FGF-2 have all demonstrated systemic vascular effects. FGF-1 and FGF-2 have been shown to reduce blood pressure in a dose-dependent manner in rats [37]. Similarly, VEGF-A has been reported to cause hypotension and death in pigs following an intracoronary bolus administration [38]. Subsequent studies have revealed that VEGF-A administration causes greater vasodilatation of coronary vessels than serotonin or nitroglycerin, and also causes tachyphylaxis via a nitric oxide-dependent mechanism [39]. VEGF-A administration to the extremities of patients has also been associated with hypotension and edema [40]. These side effects can be partly explained by the fact that VEGF-A is a potent vascular permeability factor.

\section{VEGF-A isoforms in angiogenesis therapy}

The five VEGF-A protein isoforms in humans (and at least three major isoforms in the mouse) have different biochemical and biological properties [41]. It is therefore important to determine whether different VEGF-A isoforms give rise to different quality or quantity of vessels. Expression of the various isoforms during development is modulated both spatially and temporally [42], and observations from gene knockout studies have proven that these isoforms do not have equivalent biological functions during vessel development [42,43*0]. Furthermore, there is considerable variability in the phenotype of vessels in tumors expressing different isoforms [44]. For example, vessels within tumors expressing predominantly the VEGF189 isoform, which has a strong heparin-binding affinity and thus is highly localized, are much less leaky than the vessels in tumors expressing the more diffusible VEGF165 and VEGF121 isoforms [45]. It will be interesting and impor- tant to determine whether these observations from experimental systems can help predict the results of clinical trials, which primarily employ the VEGF165 isoform. Finally, since multiple VEGF-A isoforms are expressed during vascular development [42], it will also be important to determine whether the use of multiple isoforms in angiogenesis therapy will be necessary to replicate in vivo conditions.

\section{Achieving vessel stability}

The induction of new vessels to supply ischemic tissues is the primary goal of angiogenic therapy. Reaching this objective is, however, highly complex. Vessels formed in response to artificial angiogenic stimuli are prone to regression unless they are remodeled into mature, stable vessels [46]. Thus, as the level of knowledge regarding the mechanisms of vessel growth and stabilization increases, there is increasing concern that the simple application of a bolus of angiogenic factor may be insufficient for stable vessel formation, or may even be dangerous.

Early studies involving the administration of VEGF-A showed angiographic evidence of new vessel formation, but these vessels did not persist and they regressed within 3 months [40]. It was recently reported that continuous delivery of VEGF-A into murine hearts by retroviral transfer led to the formation of aberrant vessels and hemangioma-like structures [23*0. One of the major problems encountered in the use of VEGF-A is that vessels formed are unstable and leaky [47]. It has been speculated that VEGF-A alone may not be sufficient to form stable, mature vessels that are characterized by the recruitment of the perivascular mural cells, such as pericytes or smooth muscle cells [48]. This process of vessel maturation is called arteriogenesis and is arguably the ideal way to form stable vessels for therapeutic purposes [49].

\section{Administration of multiple factors}

Various growth factors such as angiopoietin (ang)-1, plateletderived growth factor, transforming growth factor- $\beta$ as well as VEGF-A are also involved in arteriogenesis, and it may therefore be necessary to use combinations of these factors to obtain stable and mature vessels (Fig. 1). Indeed, when VEGF-A and ang-1 are administered together in animal models, the resulting vessels are much more stable and less leaky than those that are induced by VEGF-A alone [50]. Similarly, administration of submaximal doses of ang-1 and VEGF-A in a rabbit ischemic hind limb model led to a stronger effect on resting and maximal blood flow and capillary formation than either of the agents alone [51].

\section{Using a master switch gene}

Another approach that addresses the involvement of multiple factors in therapeutic angiogenesis is the use of a so-called 'master switch gene' of angiogenesis, such as HIF-1 $\alpha$ [52]. This transcription factor can activate a collection of different genes that are involved in angiogenesis, including those encoding VEGF-A, VEGF receptor 1 (Flt-1), and ang-2 


\section{Formation of a Stable Vessel}

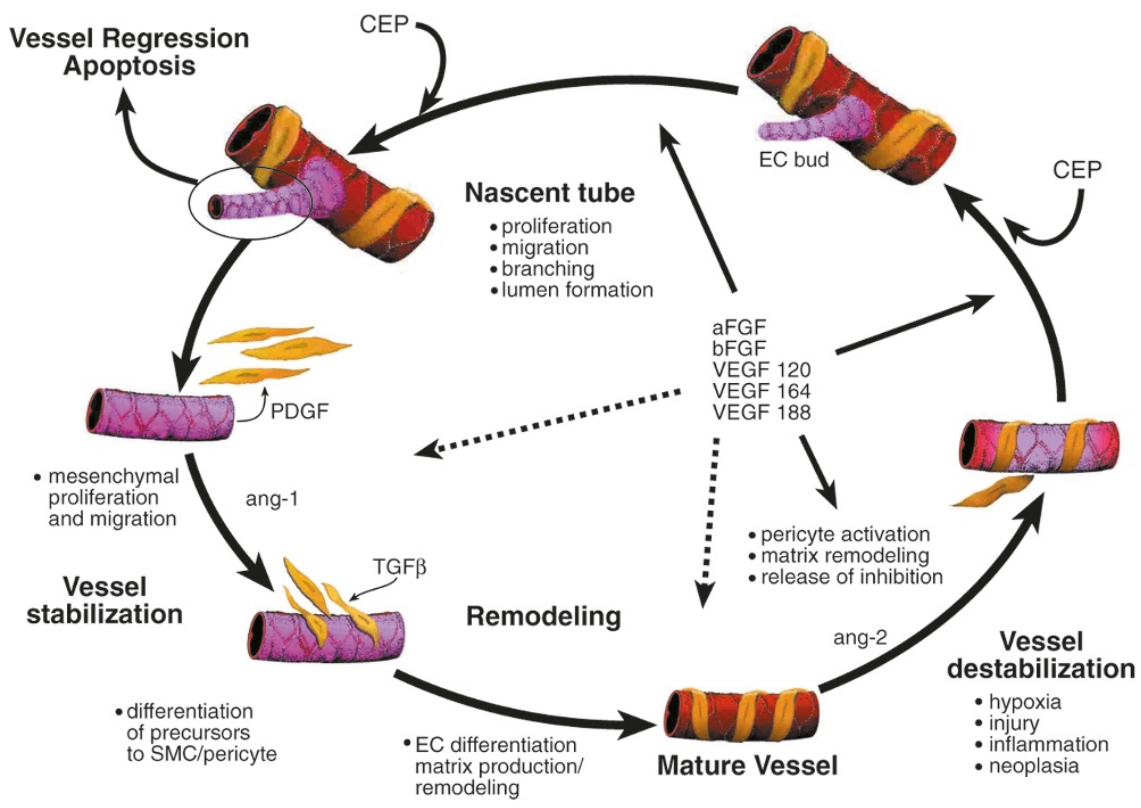

Assembly of a stable vessel. Local increases in angiogenic factors such as fibroblast growth factor (FGF) and vascular endothelial growth factor (VEGF) during new vessel formation destabilize a portion of an existing vessel (usually a venule). Destabilization is associated with increased angiopoietin (ang)-2 expression and with pericyte activation, matrix remodeling, and induction of pericyte and endothelial cell (EC) migration and proliferation. Newly formed vessels may be dependent on exogenous factors for their survival until they have been remodeled to mature structures. Remodeling involves EC recruitment of pericyte/smooth muscle cell (SMC) precursors via endothelial-derived platelet-derived growth factor (PDGF). Once the mural cell precursor makes contact with the vessel, transforming growth factor (TGF)- $\beta$ is activated, which in turn suppresses the proliferation and migration and induces the differentiation into SMC/pericytes. In addition to TGF- $\beta$, ang-1 produced by the SMC/pericytes is also involved in the stabilization and maintenance of the stable mature vessel. aFGF, acidic fibroblast growth factor; bFGF, basic fibroblast growth factor; CEP, circulating endothelial precursor.

[53,54]. It is hoped that using a 'master switch gene' will result in more stable vessels, because the processes by which they are formed would resemble more closely those of normal vessel development.

\section{Stem cells in therapeutic angiogenesis}

The existence of circulating endothelial precursor (CEP) cells in adults has been reported $\left[55^{\bullet *}, 56\right]$. It has also been demonstrated that similar precursor cells may give rise to both endothelial cells and perivascular mural cells [57]. Furthermore, in an in vitro model of angiogenesis, normal vascular development has been shown to require the presence of the CD45+/c-Kit ${ }^{+} / \mathrm{CD} 34^{+}$hematopoietic stem cells [58], which are similar and may be related to adult CEP cells.

It has been reported that CEP cells are able to participate in new vessel growth in a variety of animal models, including the rabbit ischemic hind limb model [59]. In patients with inoperable coronary disease, increased circulating VEGF-A resulting from transfection of myocardium with VEGF165 cDNA led to a significant mobilization of CEP cells [31]. Another recent publication has shown that granulocyte-colony stimulating factor mobilized CD34+ ${ }^{+}$cells, including endothelial cell precursors with phenotypic and functional characteristics of embryonic angioblasts [60*]. When injected into rats with experimental myocardial infarction, these CD34+ cells contributed to new vessel growth, which led to decreased cardiomyocyte apoptosis, to reduced remodeling, and to improved cardiac function.

Further studies of how CEP cells are released from bone marrow and to what extent they participate in postnatal angiogenesis will certainly provide valuable information regarding the therapeutic potential of CEP cells. The possibility of using CEP cells, both alone and in combination with different angiogenic growth factors, represents a promising means of obtaining stable vessels. Finally, since the use of CEP cells would allow easy ex vivo gene transfer, combining growth factor-induced therapeutic angiogenesis with gene therapy delivered via CEP should also be a promising approach.

\section{Conclusion}

As research into therapeutic angiogenesis progresses, new information regarding the control of vessel remodeling and 
stability will be incorporated into treatment strategies. Better designed studies and clinical trials that consider the issues discussed, coupled with well-defined and quantitative endpoints, will facilitate the development of novel and effective therapeutic approaches for ischemic diseases.

\section{Competing interests}

None declared.

\section{References}

Articles of particular interest have been highlighted as:

- of special interest

- of outstanding interest

1. Powers C, McLeskey SW, Wellstein A: Fibroblast growth factors, their receptors and signaling. Endocr Relat Cancer 2000, 7:165-197.

2. Leung DW, Cachianes G, Kuang W-J, Goeddel DV, Ferrara N: Vascular endothelial growth factor is a secreted angiogenic mitogen. Science 1989, 246:1306-1309.

3. Senger DR, Galli SJ, Dvorak AM, Peruzzi CA, Harvey VS, Dvorak HF: Tumor cells secrete a vascular permeability factor that promotes accumulation of ascites fluid. Science 1983, 219: 983-985.

4. Tischer E, Mitchell R, Hartman T, Silva M, Gospodarowicz D, Fiddes JC, Abraham JA: The human gene for vascular endothelial growth factor. Multiple proteins are encoded through alternative exon splicing. J Biol Chem 1991, 266:1194711954.

5. Shima DT, Kuroki M, Deutsch U, Ng Y-S, Adamis AP, D'Amore $P A$ : The mouse gene for vascular endothelial growth factor. Genomic structure, definition of the transcriptional unit and characterization of transcriptional and post-transcriptional regulatory sequences. J Biol Chem 1996, 271:3877-3883.

6. Takeshita S, Zheng LP, Brogi E, Kearney M, Pu L-Q, Bunting S, Ferrara N, Symes JF, Isner JM: Therapeutic angiogenesis. A single intraarterial bolus of vascular endothelial growth factor augments neovascularization in a rabbit ischemic hind limb model. J Clin Invest 1994, 93:662-670.

7. Tsurumi Y, Takeshita S, Chen D, Kearney M, Rossow ST, Passeri J, Horowitz JR, Symes JF, Insner JM: Direct intramuscular gene transfer of naked DNA encoding vascular endothelial growth factor augments collateral development and tissue perfusion. Circulation 1996, 94:3281-3290.

8. Pearlman JD, Hibberd MG, Chuang ML, Harada K, Lopez JJ, Gladstone SR, Friedman M, Sellke FW, Simons M: Magnetic resonance mapping demonstrates benefits of VEGF-induced myocardial angiogenesis. Nat Med 1995, 1:1085-1089.

9. Lopez JJ, Laham RJ, Stamler A, Pearlman JD, Bunting S, Kaplan A, Carrozza JP, Sellke FW, Simons M: VEGF administration in chronic myocardial ischemia in pigs. Cardiovasc Res 1998, 40: 272-281.

10. Harada K, Friedman M, Lopez JJ, Wang SY, Li J, Prasad PV, Pearlman JD, Edelman ER, Sellke FW, Simons M: Vascular endothelial growth factor administration in chronic myocardial ischemia. Am J Physiol 1996, 270:H1791-H1802.

11. Giordano FJ, Ping P, McKirnan MD, Nozaki S, DeMaria AN, Dillmann WH, Mathieu-Costello O, Hammond HK: Intracoronary gene transfer of fibroblast growth factor-5 increases blood flow and contractile function in an ischemic region of the heart. Nat Med 1996, 2:534-539.
12. Simons M, Bonow RO, Chronos NA, Cohen DJ, Giordano FJ, Hammond HK, Laham RJ, Li W, Pike M, Sellke FW, Stegmann TJ, Udelson JE, Rosengart TK: Clinical trials in coronary angiogenesis: issues, problems, consensus: An expert panel summary. Circulation 2000, 102:E73-E86.

13. Thompson WD, Li WW, Maragoudakis M: The clinical manipulation of angiogenesis: pathology, side-effects, surprises, and opportunities with novel human therapies. J Pathol 2000, 190: 330-337

14. Schumacher B, Pecher $P$, von Specht BU, Stegmann T: Induction of neoangiogenesis in ischemic myocardium by human growth factors: first clinical results of a new treatment of coronary heart disease. Circulation 1998, 97:645-650.

15. Laham RJ, Chronos NA, Pike M, Leimbach ME, Udelson JE, Pearlman JD, Pettigrew RI, Whitehouse MJ, Yoshizawa C, Simons M: Intracoronary basic fibroblast growth factor (FGF-2) in patients with severe ischemic heart disease: results of a phase I open-label dose escalation study. J Am Coll Cardiol 2000, 36:2132-2139.

16. Udelson JE, Dilsizian V, Laham RJ, Chronos N, Vansant J, Blais M, Galt JR, Pike M, Yoshizawa C, Simons M: Therapeutic angiogenesis with recombinant fibroblast growth factor-2 improves stress and rest myocardial perfusion abnormalities in patients with severe symptomatic chronic coronary artery disease. Circulation 2000, 102:1605-1610.

17. Losordo DW, Vale PR, Symes JF, Dunnington CH, Esakof DD, Maysky M, Ashare AB, Lathi K, Isner JM: Gene therapy for myocardial angiogenesis: initial clinical results with direct myocardial injection of phVEGF165 as sole therapy for myocardial ischemia. Circulation 1998, 98:2800-2804.

18. Rosengart TK, Lee LY, Patel SR, Sanborn TA, Parikh M, Bergman GW, Hachamovitch R, Szulc M, Kligfield PD, Okin PM, Hahn RT, Devereux RB, Post MR, Hackett NR, Foster T, Grasso TM, Lesser $\mathrm{ML}$, Isom OW, Crystal RG: Angiogenesis gene therapy: phase I assessment of direct intramyocardial administration of an adenovirus vector expressing VEGF121 cDNA to individuals with clinically significant severe coronary artery disease. Circulation 1999, 100:468-474.

19. Hendel RC, Henry TD, Rocha-Singh K, Isner JM, Kereiakes DJ, Giordano FJ, Simons M, Bonow RO: Effect of intracoronary recombinant human vascular endothelial growth factor on myocardial perfusion: evidence for a dose-dependent effect. Circulation 2000, 101:118-121.

20. Laitinen M, Hartikainen J, Hiltunen MO, Eranen J, Kiviniemi M, Narvanen $\mathrm{O}$, Makinen K, Manninen $\mathrm{H}$, Syvanne M, Martin JF, Laakso M, Yla-Herttuala S: Catheter-mediated vascular endothelial growth factor gene transfer to human coronary arteries after angioplasty. Hum Gene Ther 2000, 11:263-270.

21. Carmeliet P, Ferriera V, Breier G, Pollefeyt S, Kieckens L, Gertsenstein $M$, Fahrig $M$, Vandenhoeck A, Harpal K, Eberhardt C, Declercq C, Pawling J, Moons L, Collen D, Risau W, Nagy A: Abnormal blood vessel development and lethality in embryos lacking a single VEGF allele. Nature 1996, 380:435-439.

22. Miquerol L, Langille BL, Nagy A: Embryonic development is -• disrupted by modest increases in vascular endothelial growth factor gene expression. Development 2000, 127:3941-3946.

This paper showed that VEGF levels must be tightly controlled for a vasculature to form with normal pattern and function.

23. Lee RJ, Springer ML, Blanco-Bose WE, Shaw R, Ursell PC, Blau - HM: VEGF gene delivery to myocardium: deleterious effects of unregulated expression. Circulation 2000, 102:898-901.

These authors demonstrated that unregulated overexpression of VEGF in the heart causes cardiac failure and death, suggesting that tightly regulated VEGF expression may be critical for successful angiogenesis therapy and/or that VEGF alone is insufficient to form a stable vascular bed. 
24. Langer R: Drug delivery and targeting. Nature 1998, 392 (suppl):5-10.

25. Dewey RA, Morrissey G, Cowsill CM, Stone D, Bolognani F, Dodd NJ, Southgate TD, Klatzmann D, Lassmann H, Castro MG, Lowenstein PR: Chronic brain inflammation and persistent herpes simplex virus 1 thymidine kinase expression in survivors of syngeneic glioma treated by adenovirus-mediated gene therapy: implications for clinical trials. Nat Med 1999, 5: 1256-1263.

26. Bohl D, Naffakh N, Heard JM: Long-term control of erythropoietin secretion by doxycycline in mice transplanted with engineered primary myoblasts. Nat Med 1997, 3:299-305.

27. Rivard A, Fabre JE, Silver M, Chen D, Murohara T, Kearney M,

- Magner M, Asahara T, Isner JM: Age-dependent impairment of angiogenesis. Circulation 1999, 99:111-120.

This paper supports the concept that the ability of an individual to develop a collateral circulation is a function of age.

28. Rivard A, Berthou-Soulie L, Principe N, Kearney M, Curry C, Branellec D, Semenza GL, Isner JM: Age-dependent defect in vascular endothelial growth factor expression is associated with reduced hypoxia-inducible factor 1 activity. J Biol Chem 2000, 275:29643-29647.

29. Schultz A, Lavie L, Hochberg I, Beyar R, Stone T, Skorecki K, Lavie $\mathrm{P}$, Roguin A, Levy AP: Interindividual heterogeneity in the hypoxic regulation of VEGF: significance for the development of the coronary artery collateral circulation. Circulation 1999, 100:547-552.

30. Rohan RM, Fernandez A, Udagawa T, Yuan J, D'Amato RJ: - Genetic heterogeneity of angiogenesis in mice. Faseb J 2000, 14:871-876.

These results point to a strong genetic component in the control of angiogenesis, raising the question whether the ability to generate collateral vessels in the face of tissue ischemia is regulated, at least in part, by an as yet undefined gene product.

31. Kalka C, Tehrani H, Laudenberg B, Vale PR, Isner JM, Asahara T, Symes JF: VEGF gene transfer mobilizes endothelial progenitor cells in patients with inoperable coronary disease. Ann Thorac Surg 2000, 70:829-834.

32. Ware JA: Too many vessels? Not enough? The wrong kind? The VEGF debate continues [letter; comment]. Nat Med 2001, 7:403-404.

33. Moulton KS, Heller E, Konerding MA, Flynn E, Palinski W, Folkman $\mathrm{J}$ : Angiogenesis inhibitors endostatin or TNP-470 reduce intimal neovascularization and plaque growth in apolipoprotein E-deficient mice. Circulation 1999, 99:1726-1732.

34. Celletti FL, Waugh JM, Amabile PG, Brendolan A, Hilfiker PR, - Dake MD: Vascular endothelial growth factor enhances atherosclerotic plaque progression. Nat Med 2001, 7:425-429.

These authors demonstrated that a single intraperitoneal dose of VEGF can accelerate plague progression, raising the issue of the possible deleterious side effects of induction of angiogenesis for therapeutic purposes.

35. Isner JM: Still more debate over VEGF [Letter to the editor]. Nat Med 2001, 7:639-640.

36. Dake MM: Reply to "Still more debate over VEGF" [Letter to the editor]. Nat Med 2001, 7:640-641.

37. Cuevas P, Carceller F, Ortega S, Zazo M, Nieto I, GimenezGallego G: Hypotensive activity of fibroblast growth factor. Science 1991, 254:1208-1210.

38. Hariswala M, Horowitz JR, Esaof D, Sheriff DD, Walter J, Keyt B, Isner JM, Symes JF: VEGF improves myocardial blood flow but produces EDRF-mediated hypotension in porcine hearts. J Surg Res 1996, 63:77-82.
39. Lopez JJ, Laham RJ, Carrozza JP, Tofukuji M, Sellke FW, Bunting $S$, Simons M: Hemodynamic effects of intracoronary VEGF delivery: evidence of tachyphylaxis and NO dependence of response. Am J Physiol 1997, 273:H1317-H1323.

40. Isner J, Peiczek A, Schainfeld R, Blair R, Haley L, Asahara T, Rosenfield K, Razvi S, Walsh K, Symes JF: Clinical evidence of angiogenesis after arterial gene transfer of phVEGF165 in patients with ischaemic limb. Lancet 1996, 348:370-374.

41. Ferrara N, Davis-Smyth T: The biology of vascular endothelial growth factor. Endocrine Rev 1997, 18:4-25.

42. Ng Y-S, Rohan R, Sunday M, deMello DE, D'Amore PA: Differential expression of VEGF isoforms in mouse during development and in the adult. Dev Dyn 2001, 220:112-121.

43. Carmeliet $\mathrm{P}, \mathrm{Ng} \mathrm{Y}$-S, Nuyen $\mathrm{D}$, Theilmeier G, Brusselmans $\mathrm{K}$, - Cornelissen I, Ehler E, Kakkar VV, Stalmans I, Mattot V, Perriard JC, Dewerchin M, Flameng W, Nagy A, Lupu F, Moons L, Collen D, D'Amore PA, Shima. DT: Impaired myocardial angiogenesis and ischemic cardiomyopathy in mice lacking the vascular endothelial growth factor isoforms VEGF164 and VEGF188. Nat Med 1999, 5:495-502.

This paper demonstrates that the various VEGF isoforms are not functionally equivalent. Deletion of targeted exons, leading to mice that express only VEGF120, yields mice that die rapidly postnatally due to cardiac and pulmonary defects.

44. Grunstein J, Masbad JJ, Hickey R, Giordano F, Johnson RS: Isoforms of vascular endothelial growth factor act in coordinate fashion to recruit and expand tumor vasculature. Mol Cell Biol 2000, 20:7282-7291.

45. Cheng S-Y, Nagane M, Su Huang H-J, Cavenee WK: Intracerebral tumor-associated hemorrhage caused by overexpression of the vascular endothelial growth factor isoforms VEGF ${ }_{121}$ and VEGF ${ }_{165}$ but not VEGF ${ }_{189}$. Proc Natl Acad Sci USA 1997, 94:12081-12087.

46. Darland DC, D'Amore PA: Blood vessel maturation: vascular development come of age. J Clin Invest 1999, 103:157-158.

47. Dvorak HF, Nagy JA, Feng D, Brown LF, Dvorak AM: Vascular permeability factor/vascular endothelial growth factor and the significance of microvascular permeability in angiogenesis. Curr Topics Microbiol Immunol 1999, 237:97-132.

48. D'Amore PA, Ng Y-S, Darland DK: Angiogenesis. Sci Med 1999, 6:44-53.

49. Buschmann I, Schaper W: The pathophysiology of the collateral circulation (arteriogenesis). J Pathol 2000, 190:338-342.

50. Thurston G, Suri C, Smith K, McClain J, Sato TN, Yancopoulos GD, McDonald DM: Leakage-resistant blood vessels in mice transgenically overexpressing angiopoietin-1. Science 1999, 286:2511-2514

51. Chae JK, Kim I, Lim ST, Chung MJ, Kim WH, Kim HG, Ko JK, Koh GY: Coadministration of angiopoietin-1 and vascular endothelial growth factor enhances collateral vascularization. Arterioscler Thromb Vasc Biol 2000, 20:2573-2578.

52. Li J, Post M, Volk R, Gao Y, Li M, Metais C, Sato K, Tsai J, Aird W, Rosenberg RD, Hampton TG, Li J, Sellke FW, Carmeliet P, Simons M: PR39, a peptide regulator of angiogenesis. Nat Med 2000, 6:49-55.

53. Oh H, Takagi H, Suzuma K, Otani A, Matsumura M, Honda Y: Hypoxia and vascular endothelial growth factor selectively upregulate angiopoietin-2 in bovine microvascular endothelial cells. J Biol Chem 1999, 274:15732-15739.

54. Semenza GL: HIF-1 and human disease: one highly involved factor. Genes Dev 2000, 14:1983-1991. 
55. Asahara T, Murohara T, Sullivan A, Silver M, van der Zee R, Li T,

- Witzenbichler B, Schatteman G, Isner JM: Isolation of putative progenitor endothelial cells for angiogenesis. Science 1997, 275:964-967.

This paper was among the first to report the isolation of CEP cells from peripheral blood in the adult.

56. Shi Q, Rafii S, Hong-De Wu M, Wijelath ES, Yu C, Ishida A, Fujita Y, Kothari S, Mohle R, Sauvage LR, Moore MAS, Storb RF, Hammond WP: Evidence for circulating bone marrow-derived endothelial cells. Blood 1998, 92:362-367.

57. Yamashita J, Itoh $\mathrm{H}$, Hirashima M, Ogawa M, Nishikawa S, Yurugi T, Nalto M, Kalao K, Nishikawa SI: Flk1-positive cells derived from embryonic stem cells serve as vascular progenitors. Nature 2000, 408:92-96.

58. Takakura N, Watanabe T, Suenobu S, Yamada Y, Noda T, Ito Y, Satake M, Suda T: A role for hematopoietic stem cells in promoting angiogenesis. Cell 2000, 102:199-209.

59. Asahara $T$, Masuda $H$, Takahashi $T$, Kalka C, Pastore C, Silver M, Kearne M, Magner M, Isner JM: Bone marrow origin of endothelial progenitor cells responsible for postnatal vasculogenesis in physiological and pathological neovascularization. Circulat Res 1999, 85:221-228.

60. Kocher AA, Schuster MD, Szabolcs MJ, Takuma S, Burkhoff D,

- Wang J, Homma S, Edwards NM, Itescu S: Neovascularization of ischemic myocardium by human bone-marrow-derived angioblasts prevents cardiomyocyte apoptosis, reduces remodeling and improves cardiac function. Nat Med 2001, 7: 430-436.

This is the first demonstration that bone-marrow-derived endothelial cell precursors can contribute to new vessel growth in an experimental model of tissue ischemia to the extent that they impact tissue survival and function. 